\title{
Functional and structural changes of the human proximal small intestine after cytotoxic therapy
}

\author{
DAVID CUNNINGHAM,* ROGER J MORGAN, $\dagger$ PETER R MILLS, $\uparrow$ \\ LESLEY M NELSON, $\uparrow$ PETER G TONER, $\ddagger$ MICHAEL SOUKOP, ${ }^{*}$ COLIN S MCARDLE,§ \\ ROBIN I RUSSELL $\dagger$
}

From the *Department of Medical Oncology, the †Gastroenterology Unit, and the $\ddagger$ University Departments of Pathology and §Surgery, Royal Infirmary, Glasgow

SUMMARY The effects of cytotoxic therapy on the structure and function of the proximal jejunum were studied in six patients receiving intravenous cyclophosphamide $\left(300 \mathrm{mg} / \mathrm{m}^{2}\right)$, methotrexate $\left(40 \mathrm{mg} / \mathrm{m}^{2}\right)$, and 5 -fluorouracil $\left(600 \mathrm{mg} / \mathrm{m}^{2}\right)$ as adjuvant therapy for breast cancer. Using a steady state, triple lumen tube perfusion system the absorption of water and electrolytes was measured before and $48 \mathrm{~h}$ after administration of the cytotoxic agents. Jejunal biopsies were obtained at each perfusion. Median (range) water absorption fell from 126 (40-142) to 84 (46-142) $\mathrm{ml} / \mathrm{h} / 30 \mathrm{~cm}$, with parallel changes for electrolytes; none of the changes was significant. Brush border disaccharidases did not change at $48 \mathrm{~h}$ after chemotherapy, while mature enterocytes appeared normal by both light and electron microscopy. Crypt cells and immature enterocytes, however, showed focal vacuolation by light microscopy, corresponding to the occurrence of large residual bodies (secondary lysosomes) containing partially degraded fragments of damaged crypt cells. The confinement of ultrastructural changes to the immature cell population may explain the failure of this study to show a consistent change in the absorptive function of the jejunum $48 \mathrm{~h}$ after chemotherapy.

Cytotoxic therapy can cause structural and functional changes in the human proximal intestine. ${ }^{1-3}$ This effect may be important in the development of gastrointestinal symptoms such as diarrhoea and may lead to malabsorption of orally administered drugs, including cytotoxic agents. ${ }^{45}$ Smith et al ${ }^{6}$ could find no change in xylose absorption and faecal fat estimation in patients with biopsy proved depression of crypt cell mitosis, but most previous studies of cytotoxic damage have examined changes of gastrointestinal function and structure independently.

The technique of small intestinal perfusion is a sensitive method for detecting changes in the transport of water and electrolytes across the jejunal mucosa and might therefore show relatively minor abnormalities of enterocyte function more readily than conventional intestinal absorption tests. ${ }^{7}$ We have used small intestinal perfusion to investigate

IPresent address: Institute of Pathology, The Queen's University of Belfast, Royal Victoria Hospital, Grosvenor Road, Belfast.

Accepted for publication 21 November 1984 the effects of cytotoxic agents on enterocyte function and have correlated these effects with concurrent histopathological and ultrastructural changes in the proximal jejunum. On the basis of a previous study of children receiving methotrexate ${ }^{8}$ a time point $48 \mathrm{~h}$ after chemotherapy was selected for the investigation.

\section{Material and methods}

\section{PATIENTS}

Six women, mean age 47 years (range 43-60), who were receiving adjuvant chemotherapy for breast cancer entered the study. The chemotherapy consisted of cyclophosphamide $300 \mathrm{mg} / \mathrm{m}^{2}$, methotrexate $40 \mathrm{mg} / \mathrm{m}^{2}$, and 5-fluorouracil $600 \mathrm{mg} / \mathrm{m}^{2}$ (CMF) given as an intravenous bolus on days one and eight of a 28 day cycle. Prochlorperazine $10 \mathrm{mg}$ was given intravenously as an antiemetic. Five patients had previously received two cycles of CMF and one patient (patient 1 ) had received four cycles (Table 1). All patients were in complete clinical remission and none had a history of gastrointestinal disease. To be eligible for inclusion in the study the 
Table 1 Absorption of water and electrolytes before and $48 \mathrm{~h}$ after chemotherapy and development of gastrointestinal symptoms

\begin{tabular}{|c|c|c|c|c|c|c|c|c|c|c|c|}
\hline \multirow{2}{*}{$\begin{array}{l}\text { Patient } \\
\text { no }\end{array}$} & \multicolumn{2}{|c|}{$\begin{array}{l}\text { Water } \\
(\mathrm{ml} / \mathrm{h} / 30 \mathrm{~cm})\end{array}$} & \multicolumn{2}{|c|}{$\begin{array}{l}\text { Sodium } \\
(\mathrm{mmol} / \mathrm{h} / 30 \mathrm{~cm})\end{array}$} & \multicolumn{2}{|c|}{$\begin{array}{l}\text { Chloride } \\
(\mathrm{mmol} / \mathrm{h} / 30 \mathrm{~cm})\end{array}$} & \multicolumn{2}{|l|}{ Vomiting } & \multicolumn{2}{|l|}{ Diarrhoea } & \multirow{2}{*}{$\begin{array}{l}\text { Oral } \\
\text { mucositis }\end{array}$} \\
\hline & Before & After & Before & After & Before & After & $\begin{array}{l}\text { Onset } \\
\text { (h after CMF) }\end{array}$ & $\begin{array}{l}\text { Duration } \\
\text { (h) }\end{array}$ & $\begin{array}{l}\text { Onset } \\
(h \text { after } C M F)\end{array}$ & $\begin{array}{l}\text { Duration } \\
\text { (h) }\end{array}$ & \\
\hline $\begin{array}{l}1 \\
2 \\
3 \\
4 \\
5 \\
6\end{array}$ & $\begin{array}{r}103 \\
123 \\
142 \\
137 \\
40 \\
129\end{array}$ & $\begin{array}{r}142 \\
84 \\
84 \\
46 \\
55 \\
98\end{array}$ & $\begin{array}{l}10 \cdot 7 \\
10 \\
14 \\
10 \\
3 \\
14\end{array}$ & $\begin{array}{r}12 \\
9 \\
6 \\
6 \\
5 \\
10\end{array}$ & $\begin{array}{r}9 \\
9 \\
11 \\
12 \\
3 \\
13\end{array}$ & $\begin{array}{r}12 \\
8 \\
6 \\
3 \\
5 \\
9\end{array}$ & $\begin{array}{l}12 \\
\text { None } \\
4 \\
48 \\
12 \\
12\end{array}$ & $\begin{array}{r}24 \\
12 \\
6 \\
16 \\
12\end{array}$ & $\begin{array}{c}\text { None } \\
\text { None } \\
\text { None } \\
24 \\
6 \\
\text { None }\end{array}$ & $\begin{array}{l}- \\
- \\
4 \\
5\end{array}$ & $\begin{array}{l}\text { None } \\
\text { None } \\
\text { None } \\
\text { None } \\
\text { Present } \\
\text { None }\end{array}$ \\
\hline
\end{tabular}

$\mathrm{CMF}=$ cyclophosphamide, methotrexate, 5-fluoruracil.

following parameters had to be normal: haemoglobin concentration, white cell and platelet counts, serum urea and electrolyte concentrations, serum liver function tests, and serum $B_{12}$, serum folate, and red blood cell folate values. The study protocol was approved by the Ethical Committee of Glasgow Royal Infirmary and all patients gave informed consent.

\section{PERFUSION TECHNIQUE}

Full details of the perfusion technique have been described previously.' A steady state, triple lumen tube perfusion system with a mixing segment of $10 \mathrm{~cm}$ and a test segment of $30 \mathrm{~cm}$ was passed into the proximal jejunum and the radiological position confirmed before and after the perfusion. The perfusate was infused at $15 \mathrm{ml} / \mathrm{min}$ over a period of $50 \mathrm{~min}$ to achieve a steady state and samples $(4 \times$ $10 \mathrm{~min}$ ) were then collected simultaneously from the proximal and distal collection points at a rate of $2 \mathrm{ml} / \mathrm{min}$. Carbon-14 labelled polyethylene glycol was used as a water soluble non-absorbable marker in the system. Absorption of water, sodium, and chloride was measured before and $48 \mathrm{~h}$ after administration of CMF on day one of the cycle.

\section{JEJUNAL BIOPSY}

Biopsy of the jejunum was performed using a Crosby capsule (incorporated into the perfusion system) before and $48 \mathrm{~h}$ after chemotherapy. Material obtained was submitted for measurement of brush border disaccharidases, ${ }^{,}$and for light and electron microscopy.

\section{HISTOPATHOLOGY}

Biopsy material was fixed in formol-saline, embedded in paraffin, and stained with haematoxylin and eosin. In addition, a small portion of each specimen was prepared for transmission electron microscopy by glutaraldehyde fixation and embedding in EMIX epoxy resin. Semithin sections were stained by toluidine blue for light microscopy. Ultrathin sections were stained by uranyl acetate and lead citrate before examination in a Phillips EM 301 and JEOL 1200 EX electron microscope.

\section{SYMPTOMS AFTER CHEMOTHERAPY}

For the $48 \mathrm{~h}$ before and $48 \mathrm{~h}$ after chemotherapy patients were provided with diaries to document episodes of vomiting and number of bowel motions and were asked about the development of relevant symptoms including mucositis.

\section{STATISTICAL ANALYSIS}

Values for water, electrolytes, and disaccharidases before and after chemotherapy were compared using Wilcoxon's matched pairs, signed ranks test.

Table 2 Measurement of brush border disaccharidases (units of enzyme activity) before and $48 h$ after chemotherapy

\begin{tabular}{|c|c|c|c|c|c|c|}
\hline \multirow{2}{*}{$\begin{array}{l}\text { Patient } \\
\text { no }\end{array}$} & \multicolumn{2}{|l|}{ Lactase } & \multicolumn{2}{|l|}{ Sucrase } & \multicolumn{2}{|l|}{ Maltase } \\
\hline & Before & After & Before & After & Before & After \\
\hline $\begin{array}{l}1 \\
2 \\
3 \\
4 \\
5 \\
6\end{array}$ & $\begin{array}{r}11.3 \\
12.6 \\
8.2 \\
4.6 \\
8.0 \\
7.7\end{array}$ & $\begin{array}{r}11.3 \\
13.0 \\
4.6 \\
6.5 \\
7.0 \\
7.0\end{array}$ & $\begin{array}{r}9.3 \\
11.3 \\
7.9 \\
4.0 \\
13.7 \\
6.8\end{array}$ & $\begin{array}{r}8 \cdot 5 \\
11 \cdot 2 \\
4 \cdot 1 \\
10 \cdot 8 \\
12 \cdot 0 \\
7 \cdot 1\end{array}$ & $\begin{array}{l}29 \cdot 3 \\
44.0 \\
28.9 \\
16.7 \\
43 \cdot 0 \\
29 \cdot 2\end{array}$ & $\begin{array}{l}33.4 \\
47.9 \\
16 \cdot 2 \\
43 \cdot 5 \\
42 \cdot 1 \\
25.9\end{array}$ \\
\hline
\end{tabular}

Normal range of activity in units: lactase $0.2-19$; sucrase $6-17$; maltase $13-54$. (1 unit is the activity hydrolysing one micromol of disaccharide per minute per gram of tissue). 


\section{Results}

\section{PERFUSION}

Table I summarises the jejunal absorption of water and electrolytes before and after chemotherapy. Median (range) water absorption fell from 126 $(40-142)$ to $84(46-142) \mathrm{ml} / \mathrm{h} / 30 \mathrm{~cm}$, sodium from $10(3-14)$ to $7 \cdot 5(7-12) \mathrm{mmol} / \mathrm{h} / 30 \mathrm{~cm}$, and chloride from $10(3-13)$ to $7(3-12) \mathrm{mmol} / \mathrm{h} / 30 \mathrm{~cm}$; none of the changes was significant.

\section{JEJUNAL BIOPSIES}

Biopsies were successfully obtained at each perfusion. Brush border disaccharidases did not change after chemotherapy (Table 2). Control biopsies taken before chemotherapy were normal by both light and electron microscopy.

Biopsies taken after chemotherapy showed no histological changes of villous pattern. Focal abnormalities were, however, present in the intestinal crypts and occasionally on the lowest parts of the intestinal villi. Occasional cells in these locations displayed vacuoles containing pyknotic haematoxyphilic debris, changes which were more clearly seen in semithin resin sections than in paraffin sections. Electron microscopy confirmed the occurrence of focal crypt cell vacuolation, which was due to the presence of large secondary lysosomes containing cell debris. The vacuoles were at times larger than, and often indented, the crypt cell nucleus (Fig. 1).
The vacuole generally appeared membrane limited and contained variable amounts of recognisable but partially degraded cellular debris suspended in electron lucent background material (Fig. 2). Occasionally, crypt cells undergoing mitosis contained similar lysosomal inclusions (Fig. 3). No significant abnormalities were detected in the mature enterocyte population of the post-chemotherapy villus. Microvilli, cell adhesion specialisations, and organelles such as mitochondria and membrane systems all appeared similar to controls (Fig. 4).

\section{SYMPTOMS}

No patient had vomiting or diarrhoea in the $48 \mathrm{~h}$ before chemotherapy; Table 1 shows their occurrence after treatment.

\section{Discussion}

This study showed evidence of crypt cell damage in the proximal jejunum $48 \mathrm{~h}$ after treatment with CMF but failed to show any consistent change in absorptive function. There was no correlation between the development of diarrhoea in individual patients and alteration of jejunal absorption, probably because other factors such as gastrointestinal hormones and colonic function may determine the development of diarrhoea after treatment with cytotoxic drugs.

Since Gwavava et al ${ }^{8}$ reported maximal mor-

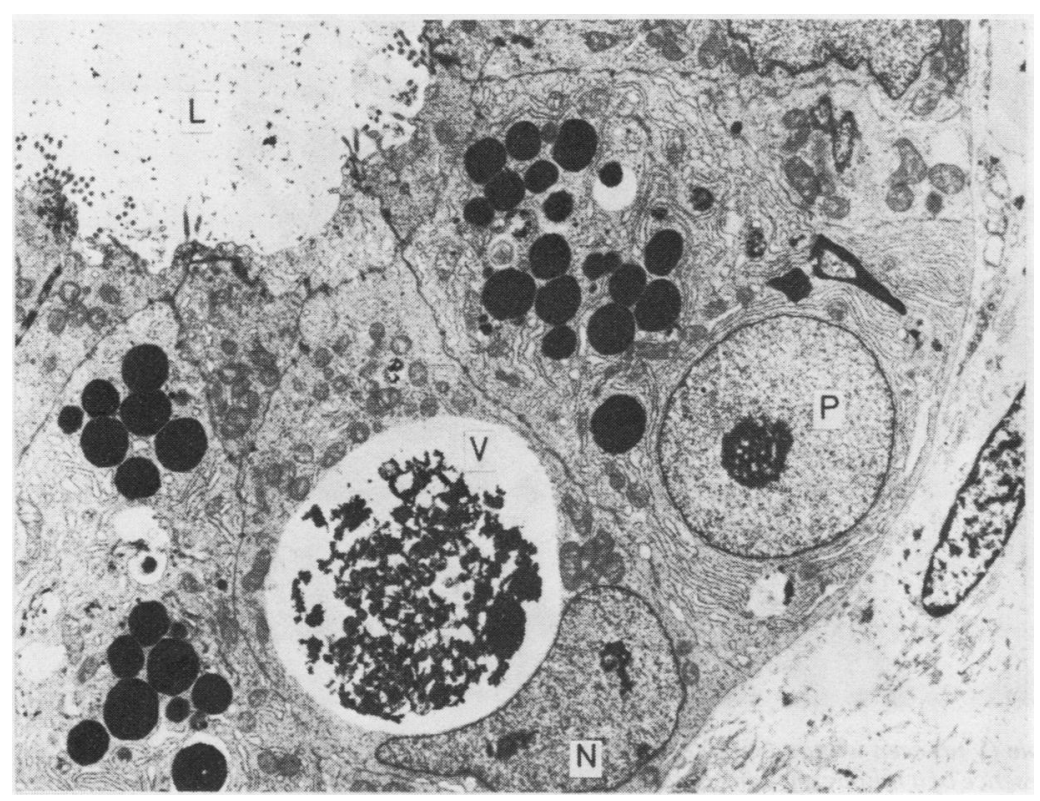

Fig. 1 Small intestinal crypt cells 48 h after chemotherapy. The crypt lumen $(L)$ is surrounded by Paneth cells $(P)$ and immature enterocytes, one of which contains a large vacuole $(V)$ containing heterogeneous dense cellular debris. The vacuole is larger than and indents the crypt cell nucleus (N). 


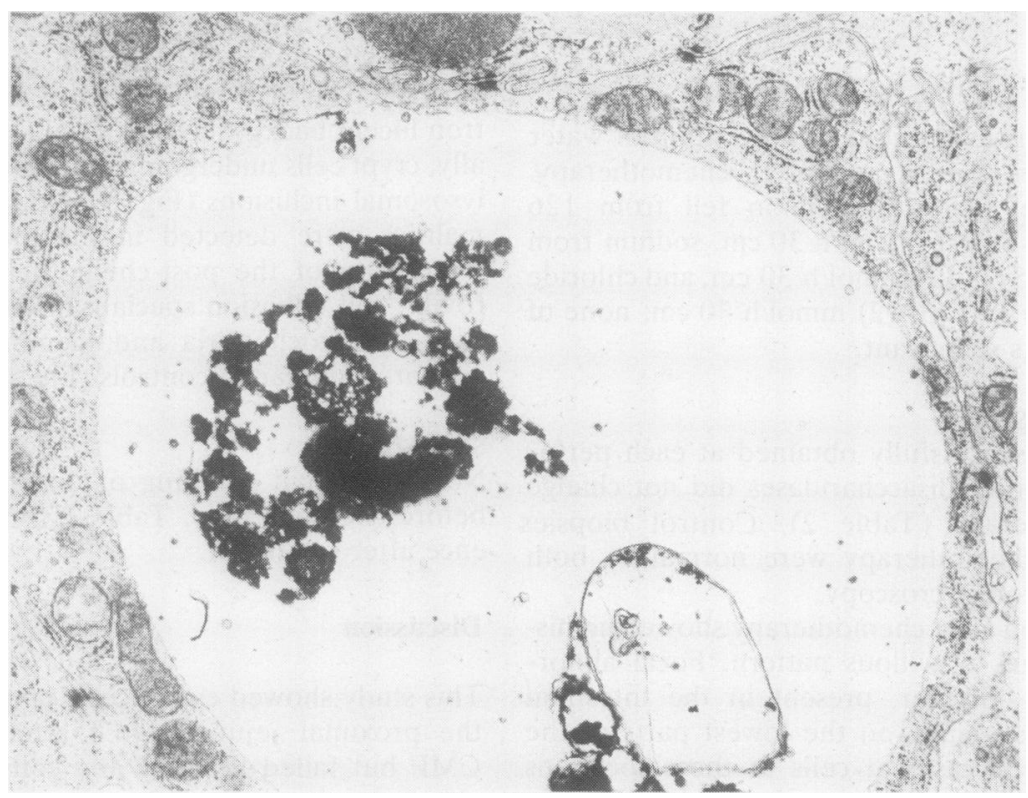

Fig. 2 A large vacuole in a crypt cell $48 \mathrm{~h}$ after chemotherapy. A limiting membrane can be distinguished. The heterogeneous dense content of the vacuole is suspended in an otherwise featureless pale background.

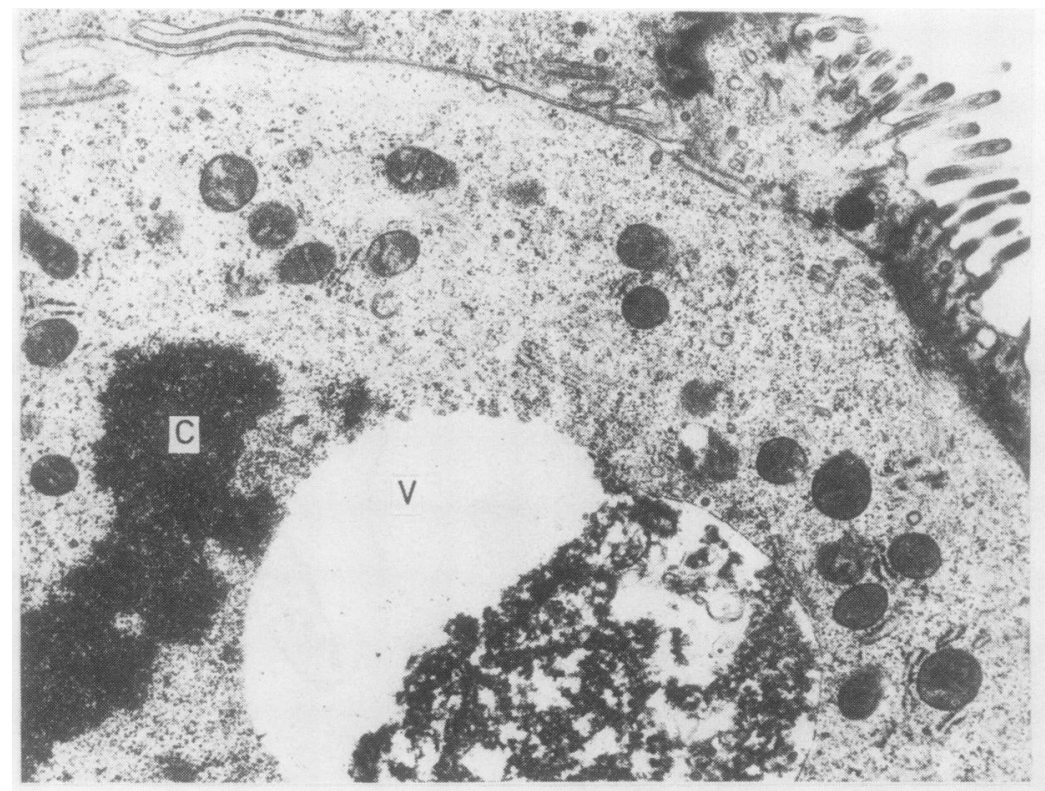

Fig. $3 A$ vacuole $(V)$ is seen within a crypt cell which is undergoing mitosis, as shown by the presence of a mitotic chromosome $(C)$ lying free within the cytoplasm. 


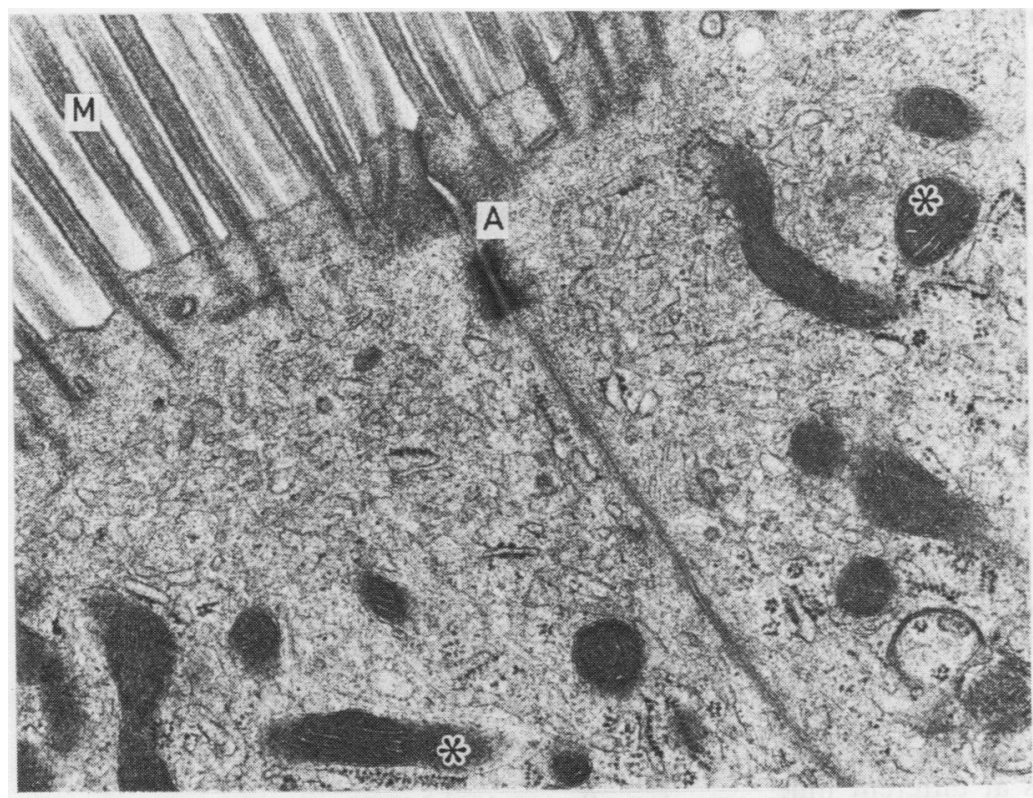

Fig. 4 Mature enterocytes $48 \mathrm{~h}$ after chemotherapy. These cells appear normal with respect to microvilli $(M)$, cell adhesions $(A)$, mitchondria $\left({ }^{*}\right)$ and cytoplasmic membrane systems. phological abnormalities in the mature villous cells in the jejunum between 24 and $72 \mathrm{~h}$ after the administration of intravenous methotrexate to children with acute lymphoblastic leukaemia, the second perfusion in the present study was performed $48 \mathrm{~h}$ after CMF treatment, which was considered likely to be the optimal time to detect a difference in intestinal perfusion. At this time, however, there was no morphological abnormality of the mature villous cells comparable to the changes described by Gwavava et al. ${ }^{8}$ The changes seen were confined, instead, largely to the crypt cells, corresponding to the observations of Trier ${ }^{1}$ at $48 \mathrm{~h}$ after administration of methotrexate. The inconsistency between the present results and the study of Gwavava et al $^{\mathbf{8}}$ may lie partly in the clinical states of the patients under investigation: the otherwise normal adult patients receiving adjuvant chemotherapy in the present study may well respond differently from a group of children with established systemic disease. Also, the differences may be explained partly on the basis of different jejunal cell turnover times in children and adults.

In the adult small intestine cell proliferation takes place in the crypt region. The quoted figures for the time scale of this process vary widely: one estimation $^{10}$ proposed that completion of the cell cycle occurs over $48 \mathrm{~h}$ and that subsequent migration of cells from the crypt to villus tip region takes a further five days. Hence, after chemotherapy there are two periods of potential mature enterocyte dysfunction: that associated with the acute cytopathic effect on the non-dividing cells of the villous region, evolving within hours, ${ }^{8}$ and that seen as a consequence of previous inhibition of division and damage to cells in the crypt proliferation zone, which is expressed in the mature villous cells five to seven days later. Since ultrastructural evidence of cell damage in the present study was localised to the crypts at the time of the second perfusion it was not surprising that a consistent functional abnormality of mature enterocytes could not be shown. It seems likely, therefore, that the damage to the proliferating compartment of cells in this adult adjuvant chemotherapy model will be reflected in functional terms at a later stage, when the corresponding cells and the effects of temporary mitotic arrest will have progressed to the middle and distal parts of the villi. Further studies of later time points are proposed to test this hypothesis.

Smith et $\mathrm{l}^{6}$ also failed to show any abnormality of small bowel function after chemotherapy using the $5 \mathrm{~h}$ D-xylose absorption test and a $72 \mathrm{~h}$ quantitative stool fat analysis. But the timing of these estimations in relation to chemotherapy was not consistent. Moreover, the cohort of patients included a number of different types receiving a variety of chemotherapeutic regimens, making overall interpretation of the data difficult. The patients in the present study were receiving uniform chemotherapy in an adjuvant setting and thus represent an ideal group in which to study the potential enteropathic effect of chemotherapy.

The effect of cytotoxic therapy on the function of 
the enterocyte is clinically relevant. For example, it has been shown among children with acute lymphoblastic leukaemia that clinical relapse in good prognostic groups was associated with impaired absorption of methotrexate and it has been suggested that variations in the absorption of methotrexate were due to methotrexate damage of the gastrointestinal tract." A similar mechanism may explain the variable bioavailability of oral etoposide. ${ }^{5}$ Furthermore, small bowel dysfunction could lead to malabsorption of essential nutrients, including vitamin A, low concentrations of which have been linked with an impaired response to chemotherapy. ${ }^{12}$

In conclusion, intravenous adjuvant chemotherapy in otherwise healthy adults produces no consistent changes in jejunal absorptive function $48 \mathrm{~h}$ after treatment. This result, which is at variance with some previous studies, is supported by the absence of ultrastructural injury to mature enterocytes; such changes which were seen were still confined to the immature cell compartment. Further studies of this group of subjects at different time points are proposed in order to establish the precise timing of any functional defect, since this may influence the scheduling of concomitantly administered oral cytotoxic drugs.

We thank Staff Nurse Linda Redman for assistance in performing the perfusion, Mr Grant Mitchell for technical assistance, and Miss Aileen Penrice for preparation of the manuscript. The JEOL 1200 EX electron microscope was purchased with the assistance of a grant from the Scottish Home and Health Department.
References

' Trier JS. Morphological alterations induced by methotrexate in the mucosa of human proximal intestine. Gastroenterology 1962;42:295-305.

${ }^{2}$ Hyman JS, Batrus CL, Grand RJ, Sallan SE. Cancer chemotherapy-induced lactose malabsorption in children. Cancer 1982;49:646-50.

${ }^{3}$ Lewis IJ, Mainwaring D, Martin J. Enteropathy complicating maintenance therapy in acute lymphoblastic leukaemia. Arch Dis Child 1982;57:663-7.

${ }^{4}$ Craft AW, Kay HEM, Lawson DN, McElwain TJ. Methotrexate-induced malabsorption in children with acute lymphoblastic leukaemia. Br Med J 1977;ii: 1511-2.

${ }^{5}$ Incalci MD, Farina P, Sessa C, et al. Pharmacokinetics of VP16213 given by different administration methods. Cancer Chemother Pharmacol 1982;7:141-5.

- Smith FP, Kisner DL, Widerlite L, Schein PS. Chemotherapeutic alterations of small intestinal morphology and function: a progress report. J Clin Gastroenterol 1979;1:203-7.

' Russell RI, Allan JG, Gerskowitch VP, Robertson JWK. A study by perfusion techniques of the absorption abnormalities in the jejunum in adult coeliac disease. Clin Sci 1972;42:735-41.

${ }^{8}$ Gwavava NJT, Pinkerton CR, Glasgow JFT, Sloan JM, Bridges JM. Small bowel enterocyte abnormalities caused by methotrexate treatment in acute lymphoblastic leukaemia of childhood. J Clin Pathol 1981;34:790-5.

' Dahlqvist A. Method of assay of intestinal disaccharidases. Analyt Biochem 1964; 7:18-25.

${ }^{10}$ Eastwood GL. Gastrointestinal epithelial renewal. Gastroen. terology 1977;72: 962-75.

"Craft WW, Rankin A, Aherne W. Methotrexate absorption in children with acute lymphoblastic leukemia. Cancer Treat Rep 1981;65:77-81.

${ }^{12}$ Soukop M, Calman KC. Vitamin A status and chemotherapeutic response. In: Siegenthaler $\mathrm{W}$, Luthy $\mathrm{R}$, eds. Current chemotherapy. Proceedings of the 10th International Congress of Chemotherapy, II. Washington DC: American Society of Microbiology, 1978:1297-8.

Requests for reprints to: Dr D Cunningham, Department of Medical Oncology, Royal Infirmary, Glasgow G4 OSF, Scotland. 